\title{
KALIBRASI KAMERA NON-METRIK DIGITAL DENGAN METODE SELF CALIBRATION
}

\author{
Bayu Angkusprana Saktia Putera, Teguh Hariyanto \\ Program Studi Teknik Geomatika FTSP-ITS, Kampus ITS Sukolilo, Surabaya, 60111 \\ Email : pranasaktia@yahoo.com,teguh_hr@geodesy.its.ac.id
}

\begin{abstract}
Abstrak
Penggunaan kamera dijital non metrik untuk aplikasi fotogrametri makin berkembang, dengan didukung oleh perkembangan perangkat lunak yang tersedia dan harga kamera dijital non metrik yang relatif murah dengan spesifikasi yang bagus. Hal ini membuat penggunaan teknologi fotogramteri rentang dekat untuk pekerjaan pemetaan semakin diminati karena memiliki keuntungan dapat menjangkau daerah yang sulit dijangkau atau memiliki dimensi yang kecil. Namun kekurangannya kamera jenis ini memiliki kualitas geometrik yang kurang baik sehingga mengakibatkan posisi pada foto yang dihasilkan kurang akurat. (Afriyanti, 2005)
\end{abstract}

Dalam penelitian ini akan dilakukan proses kalibrasi pada kamera yang akan digunakan yaitu Canon IXUS $115 \mathrm{HS}$ dengan resolusi 12 megapixel dan panjang fokus yang digunakan $11 \mathrm{~mm}$. Metode kalibrasi yang digunakan yaitu Self Calibration. Perbandingan akurasi yang dihasilkan diketahui berdasar pergeseran titik hasil proyeksi terhadap Ground Control Point (GCP) yang terukur di lapangan.

Hasil penelitian menunjukan bahwa dalam proses kalibrasi menghasilkan parameter eksternal yang stabil, karena dalam proses iterasi yang keempat hingga seterusnya nilai yang dihasilkan tidak berubah. Distorsi hasil proyeksi arah pergeserannya mendekati posisi ideal serta nilai reprojection error tidak melebihi $0.5 \mathrm{~mm}$ dari bacaan maksimal mistar $1 \mathrm{~mm}$. Parameter internal tidak menghasilkan nilai yang stabil karena dalam setiap proses iterasinya nilainya selalu berubah, panjang fokus terkalibrasi mengalami perubahan signifikan sebesar $-99 \mathrm{~mm}$ dari nilai acuan $11 \mathrm{~mm}$, dan nilai parameter external terkalibrasi berbeda jauh dari nilai awal yang diberikan.

Meskipun demikian, dapat digambarkan pola distorsi dan arah pergeseran titik-titik hasil proyeksi pada proses penentuan Exterior Orientation Parameter (EOP) serta dapat dilihat bahwa titik yang mengalami pergeseran terbesar yaitu titik 7 dengan nilai kesalahan $0.019 \mathrm{~mm}$ ke arah $\mathrm{X}$ dan $-0.0672 \mathrm{~mm}$ ke arah $\mathrm{Y}$. Titik yang mengalami pergeseran terkecil yaitu titik 8 yang berada di pusat foto dengan nilai kesalahan $-0.0026 \mathrm{~mm}$ ke arah $\mathrm{X}$ dan $0.0071 \mathrm{~mm}$ ke arah $\mathrm{Y}$.

Kata Kunci : Fotogrametri, Kalibrasi kamera, Canon IXUS115 HS, IOP, EOP

\section{PENDAHULUAN}

\section{Latar Belakang}

Penggunaan kamera dijital non metrik untuk aplikasi fotogrametri makin berkembang, dengan didukung oleh perkembangan perangkat lunak yang tersedia, turunnya harga kamera digital non metrik, serta teknologi kamera digital yang semakin berkembang membuat penggunaan teknologi fotogrametri rentang dekat dalam suatu pekerjaan pemetaan semakin diminati karena memiliki keuntungan dapat menjangkau daerah yang sulit di jangkau atau memiliki dimensi yang kecil serta biaya tidak terlalu mahal dan waktu yang relatif singkat.

Kamera non-metrik yang menjadi salah satu instrumen penting pada sebuah misi pemotretan udara sejak awal bukan didesain untuk keperluan fotogrametri. Kamera non-metrik memiliki kualitas gambar yang baik namun kualitas geometriknya kurang. Hal ini mengakibatkan penentuan posisi pada foto yang dihasilkan menjadi kurang akurat pula. Kualitas geometrik dari foto kamera non metrik dapat ditingkatkan dengan cara melakukan kalibrasi pada kamera yang digunakan. Kalibrasi kamera merupakan proses penentuan parameter internal kamera udara, untuk selanjutnya parameter-parameter ini akan dijadikan input dalam orientasi dalam.

Kamera digital jenis compact system atau sering disebut kamera saku dijital merupakan jenis kamera non metrik yang murah dan banyak tersedia di pasaran, salah satunya Canon IXUS $115 \mathrm{HS}$ yang akan digunakan dalam penelitian ini. 
Pemilihan tipe kamera ini didasarkan pada harga, berat kamera, resolusi gambar serta panjang focus lensa kamera. Canon IXUS $115 \mathrm{HS}$ merupakan jenis kamera entry level. Canon IXUS memiliki kelebihan dalam hal resolusi yaitu $14 \mathrm{MP}$, bobot yang ringan serta harga yang relatif murah, namun memiliki kekurangan dalam rentang focus nya yang hanya berkisar $5 \mathrm{~mm}$ $20 \mathrm{~mm}$ ekivalen $28 \mathrm{~mm}-112 \mathrm{~mm}$.

Metode kalibrasi yang akan dipergunakan pada penelitian ini yaitu metode self calibration, yang dapat dilakukan terpisah dengan pemotretan objek (laboratory calibration). Metode ini digunakan untuk mengkalibrasi kamera yang digunakan pada penelitian ini, yaitu Canon IXUS 115HS untuk mendapatkan nilai parameter internal kamera tersebut, sehingga dapat dianalisa ketelitiannya. Metode ini sesuai yang dilakukan oleh Kusumadarma (2008), dijelaskan bahwa metode kalibrasi self calibration dapat digunakan untuk kamera yang tidak stabil karena parameter orientasi dalam yang dihitung sesuai dengan kondisi saat pemotretan, sedangkan menurut Hanifa (2008), self-calibration merupakan metode yang sangat sesuai diterapkan pada kamera non-metrik, karena dapat mengeliminasi efek dari ketidakstabilan orientasi interior foto.

\section{Rumusan Permasalahan}

Permasalahan yang akan dibahas dalam penelitian ini meliputi analisa tingkat ketelitian dari kamera non-metrik dengan analisis parameter eksternal dan internal kamera dengan metode self calibration.

\section{Batasan Masalah/Ruang Lingkup}

Adapun batasan masalah yang diajukan dalam penelitian ini adalah sebagai berikut:

1. Melakukan analisis parameter eksternal dan internal kamera dengan menggunakan metode self calibration untuk meningkatkan ketilitian kamera Canon IXUS 115 HS.

2. Objek penelitian berupa 1 buah foto bidang kalibrasi berupa Cheeseboard dengan panjang fokus yang digunakan $11 \mathrm{~mm}$ ekiv. $61.6 \mathrm{~mm}$.

3. Pada saat pemotretan target, kamera dianggap dalam posisi tegak lurus terhadap bidang datar (tidak terjadi kemiringan).
4. Titik pusat target dianggap titik tengah foto dan posisinya tidak mengalami rotasi dan translasi (pergeseran).

5. Kamera non metrik yang digunakan adalah kamera jenis compact system Canon IXUS 115 HS.

\section{Tujuan}

Tujuan penulisan penelitian ini adalah :

1. Melakukan kalibrasi pada kamera digital non metrik menggunakan metode self calibration.

2. Melakukan analisis orientasi eksternal dan internal kamera

\section{Manfaat}

1. Mengetahui ketelitian kamera non-metrik dari hasil analisis distorsi radial dan tangensial.

2. Mengetahui sejauh mana kegunaan kamera dijital non-metrik untuk keperluan fotogrametri rentang dekat.

\section{METODOLOGI PENELITIAN}

\section{Lokasi Penelitian}

Lokasi penelitian ini di laboratorium Geospasial Teknik Geomatika ITS.

\section{Data dan Peralatan}

\section{- Data}

Data yang digunakan dalam penelitian ini adalah:

1. Foto bidang kalibrasi berupa papan catur (cheeseboard) dengan ukuran sesuai lebar sensor kamera.

2. Koordinat Foto dan Koordinat Ground Control Point (GCP).

\section{- Peralatan}

Peralatan yang digunakan dalam penelitian ini adalah:

1. Perangkat Keras (Hardware)
a. Notebook
b. Kamera Digital Canon IXUS 115HS
c. Tripod
d. Mistar

2. Perangkat Lunak (Software)
a. Autodesk Land Desktop 2009
b. Matlab 


\section{c. Microsoft Office}

\section{Pengolahan Data}

Adapun untuk diagram alir pengolahan data adalah sebagai berikut:

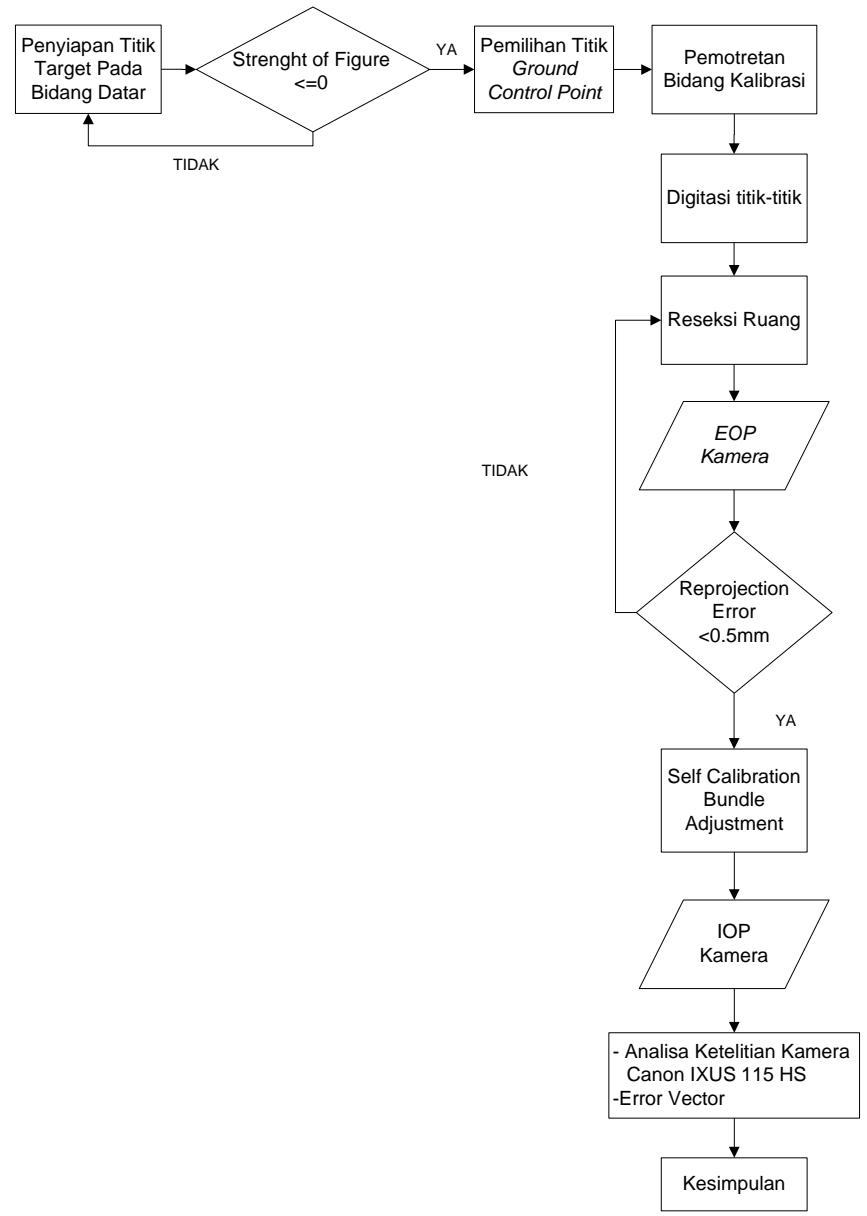

\section{Gambar 1. Diagram Alir Pengolahan Data}

Berikut ini adalah penjelasan diagram alir tahap pengolahan data :

1. Menyiapkan bidang kalibrasi, berupa grid berbentuk papan catur dengan ukuran sesuai sensor kamera yang digunakan.

2. Menghitung nilai SOF untuk menentukan kekuatan kerangka jaring Ground Control Point.

3. Pemilihan titik Ground Control Point berdasarkan nilai SOF.

4. Pemotretan bidang kalibrasi.

5. Mendijitasi titik-titik objek untuk mendapatkan koordinat pixel foto, pada saat mendigitasi sangat perlu diperhatikan urutan penomoran. Jika ada kesalahan pada urutan penomoran, maka titik target tidak dapat diproses.

6. Melakukan proses reseksi untuk mencari posisi dan orientasi kamera. Metode ini menghasilkan enam parameter orientasi luar $\left(X_{L}, Y_{L}, Z_{L}, \omega, \varphi, \kappa\right), X_{L}, Y_{L}, Z_{L}$ merupakan posisi dan orientasi kamera pada saat pemotretan. Posisi dan orientasi kamera diperlukan untuk dapat menentukan posisi dari titik objek relatif dari sistem koordinat kamera.

7. Jika nilai reprojection error lebih melibihi $0.5 \mathrm{~mm}$ dari bacaan maksimal mistar $1 \mathrm{~mm}$, maka dilakukan proses reseksi ruang kembali.

8. Melakukan bundle adjustment untuk mendapatkan nilai orientasi dalam (Parameter distorsi radial(K1, K2, K3), panjang fokus kamera ( $f$ ), Koordinat bidang kalibrasi $\left(\mathrm{X}_{0}, \mathrm{Y}_{0}\right)$.

9. Setelah mendapatkan parameter yang diinginkan maka dibandingkan dengan parameter awal yang diberikan, jika hasilnya tidak stabil maka dilakukan pengambilan foto objek kalibrasi kembali dengan memperhatikan hal-hal yang mempengaruhi kualitas foto pada saat pengambilan foto.

10. Setelah mendapatkan hasil yang mendekati sebenarnya, maka menganalisa ketelitian parameter hasil kalibrasi kamera Canon IXUS 115HS. Analisis ini terkait panjang focus terkalibrasi dan besarnya distorsi pada tahap pengambilan gambar objek dan spesifikasi kamera yang digunakan.

11. Terakhir dilakukan penarikan kesimpulan terhadap permasalahan yang dibahas dalam penelitian ini.

\section{HASIL DAN PEMBAHASAN}

\section{Analisis Stabilitas Kamera}

Analisis Parameter External Kamera

Sebelum menentukan parameter internal kamera, terlebih dahulu dilakukan penentuan parameter external kamera atau External Orientation Parameter (EOP). Hal ini diperlukan mengingat kamera digital non-metrik Canon IXUS115HS yang dipergunakan dalam penelitian ini tidak spesifik untuk digunakan dalam fotogrameteri dan patut diduga memiliki geometri yang tidak baik, sehingga perlu dilakukan kalibrasi. Pada penelitian ini menggunakan panjang focus $(f) 11 \mathrm{~mm}$. 


\section{Perhitungan Parameter External Kamera}

Secara umum, langkah yang dilakukan dalam menentukan EOP adalah sebagai berikut :

1. Menentukan koordinat foto dan koordinat Ground Control Point (GCP) dari bidang kalibrasi dalam satuan millimeter.

2. Mentranformasi koordinat pixel foto ke dalam satuan $\mathrm{mm}$.

3. Menetapkan nilai parameter EOP dengan harga pendekatan yang dihitung dengan menggunakan transformasi Affine 2D.

4. Melakukan perhitungan dengan rumus kolinearitas sehingga didapat nilai parameter EOP yang baru.

5. Memasukkan nilai EOP yang baru pada perhitungan awal sampai didapatkan nilai parameter yang stabil.

Pemotretan bidang kalibrasi dilakukan di Laboratorium Geospasial Teknik Geomatika ITS dengan menguji kamera menggunakan mode Auto, dimana secara otomatis menyesuaikan sendiri aperture, flash, dan shutter speed tergantung kondisi dan objek pemotretan.. Dalam Perhitungan EOP ini menggunakan bidang kalibrasi dengan ukuran $(617 \mathrm{~mm} \times 45.5 \mathrm{~mm})$. Dimana pemotretan dilakukan satu arah yaitu tegak lurus dengan bidang kalibrasi.

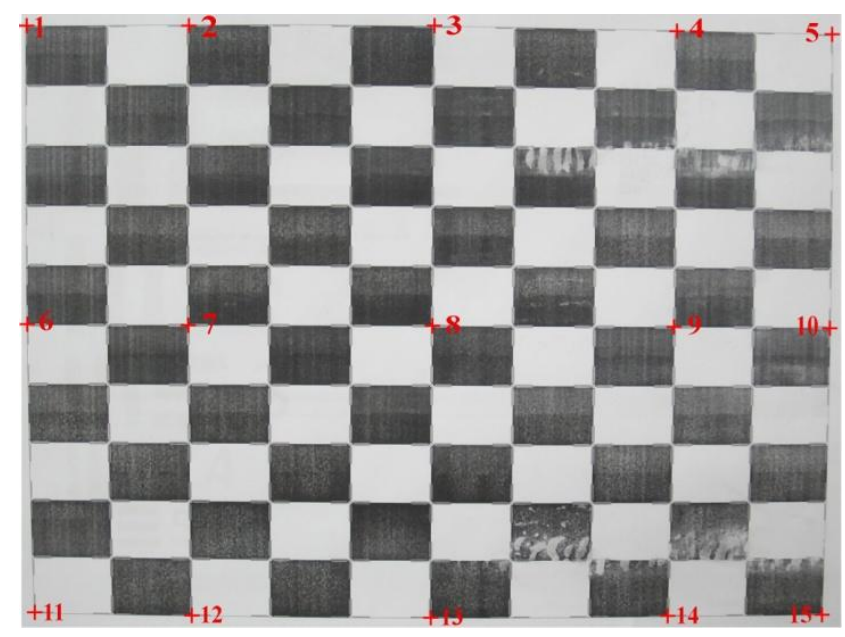

Gambar 2. Bidang kalibrasi kamera beserta 15 titik GCP

Koordinat Ground Control Point ini yaitu koordinat bidang kalibrasi yang berupa bidang datar berbentuk grid papan catur (cheeseboard). Dikarenakan grid berupa bidang datar maka dapat dimisakan nilai $Z=0 \mathrm{~mm}$.

\begin{tabular}{|c|c|c|c|}
\hline No. Titik & $X(\mathrm{~mm})$ & $Y(\mathrm{~mm})$ & $Z(\mathrm{~mm})$ \\
\hline 1 & -310 & 225 & 0 \\
\hline 2 & -186 & 225 & 0 \\
\hline 3 & 0 & 225 & 0 \\
\hline 4 & 186 & 225 & 0 \\
\hline 5 & 310 & 225 & 0 \\
\hline 6 & -310 & 0 & 0 \\
\hline 7 & -186 & 0 & 0 \\
\hline 8 & 0 & 0 & 0 \\
\hline 9 & 186 & 0 & 0 \\
\hline 10 & 310 & 0 & 0 \\
\hline 11 & -310 & -225 & 0 \\
\hline 12 & -186 & -225 & 0 \\
\hline 13 & 0 & -225 & 0 \\
\hline 14 & 186 & -225 & 0 \\
\hline 15 & 310 & -225 & 0 \\
\hline
\end{tabular}

Gambar 3. Koordinat GCP (mm)

\begin{tabular}{|c|c|c|}
\hline No. Titik & $\mathrm{X}(\mathrm{mm})$ & $\mathrm{Y}(\mathrm{mm})$ \\
\hline 1 & -3.0526 & 2.187 \\
\hline 2 & -1.8322 & 2.1946 \\
\hline 3 & 0.0208 & 2.184 \\
\hline 4 & 1.843 & 2.1551 \\
\hline 5 & 3.0271 & 2.1218 \\
\hline 6 & -3.0449 & -0.0311 \\
\hline 7 & -1.8306 & 0.0468 \\
\hline 8 & 0.0054 & $-0.0387 ;$ \\
\hline 9 & 1.8306 & $-0.0478 ;$ \\
\hline 10 & 3.0063 & $-0.0539 ;$ \\
\hline 11 & -2.9893 & $-2.1703 ;$ \\
\hline 12 & -1.809 & $-2.1900 ;$ \\
\hline 13 & -0.0085 & $-2.2082 ;$ \\
\hline 14 & 1.7797 & $-2.1961 ;$ \\
\hline 15 & 2.9415 & -2.1825 \\
\hline
\end{tabular}

Gambar 4. Koordinat Foto (mm)

Gambar 4. menyajikan koordinat foto yaitu koordinat titik-titik kontrol pada foto bidang kalibrasi yang didapat setelah melakukan transformasi koordinat pixel kedalam satuan millimeter. Koordinat pixel didapat dengan bantuan program Matlab.

\section{Perhitungan Strenght Of Figure}

Dalam perhitungan Strength of Figure akan dihasilkan 1 (SOF), dari foto bidang kalibrasi. Besaran nilai SOF yang memenuhi syarat adalah 
mendekati nol, jika SOF sudah sesuai maka desain jarring Strength of Figure dianggap kuat (Abidin, 2000)

Berikut ini merupakan desain jarring untuk perhitungan Strength of Fuigure foto bidang kalibrasi dengan 15 titik kontrol :

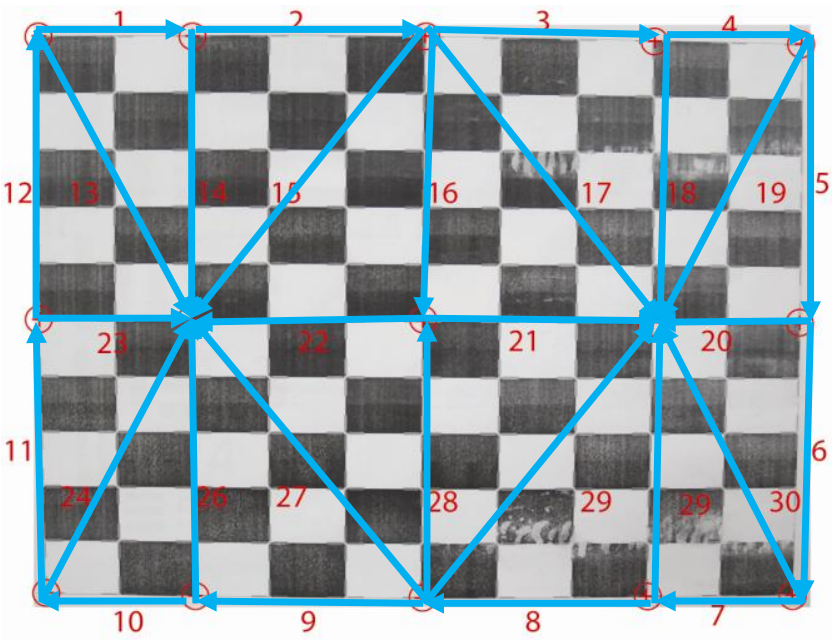

Gambar 5. Desain Jaring Foto Bidang Kalibrasi

$\begin{array}{ll}\text { Keterangan: } & \\ \text { Jumlah titik } & =15 \\ \text { Jumlah baseline } & =30 \\ \text { N Ukuran } & =90 \\ \text { N Parameter } & =45 \\ \text { U } & =45 \\ \text { SoF } & =0.00035842\end{array}$

Hasil lengkap perhitungan parameter EOP dapat dilihat pada tabel-tabel berikut:

\begin{tabular}{|c|c|c|c|c|c|c|c|c|}
\hline Iterasi & 1 & 2 & 3 & 4 & 5 & 6 & 7 & 8 \\
\hline$\omega(\mathrm{rad})$ & -0.0536 & -0.0561 & -0.0562 & -0.0562 & -0.0562 & -0.0562 & -0.0562 & -0.0562 \\
\hline$\varphi(\mathrm{rad})$ & -0.0248 & -0.0232 & -0.0232 & -0.0232 & -0.0232 & -0.0232 & -0.0232 & -0.0232 \\
\hline $\mathrm{K}(\mathrm{rad})$ & 0.0062 & 0.0062 & 0.0062 & 0.0062 & 0.0062 & 0.0062 & 0.0062 & 0.0062 \\
\hline $\mathrm{Xl}(\mathrm{mm})$ & -0.0281 & -0.0265 & -0.0265 & -0.0265 & -0.0265 & -0.0265 & -0.0265 & -0.0265 \\
\hline $\mathrm{Yl}(\mathrm{mm})$ & 0.063 & 0.0666 & 0.0668 & 0.0668 & 0.0668 & 0.0668 & 0.0668 & 0.0668 \\
\hline $\mathrm{Zl}(\mathrm{mm})$ & 1.132 & 1.129 & 1.129 & 1.129 & 1.129 & 1.129 & 1.129 & 1.129 \\
\hline
\end{tabular}

Gambar 6. Hasil perhitungan Parameter Eksternal Kamera (EOP)

\begin{tabular}{|c|c|c|c|c|c|}
\hline \multicolumn{5}{|c|}{ EOP RATA2 } \\
\hline$\omega(\mathrm{rad})$ & $\varphi(\mathrm{rad})$ & $\mathrm{\kappa}(\mathrm{rad})$ & $\mathrm{Xl}(\mathrm{mm})$ & $\mathrm{Yl}(\mathrm{mm})$ & $\mathrm{Zl}(\mathrm{mm})$ \\
\hline-0.0562 & -0.0232 & 0.0062 & -0.0265 & 0.0668 & 1.129 \\
\hline
\end{tabular}

Gambar 7. Nilai Rata-rata Parameter Eksternal Kamera (EOP)

\begin{tabular}{|c|c|c|}
\hline Titik & $X(\mathrm{~mm})$ & $Y(\mathrm{~mm})$ \\
\hline 1 & -3.0494 & 2.2094 \\
\hline 2 & -1.8183 & 2.1961 \\
\hline 3 & 0.0166 & 2.1762 \\
\hline 4 & 1.8373 & 2.1565 \\
\hline 5 & 3.0434 & 2.1434 \\
\hline 6 & -3.0289 & -0.0129 \\
\hline 7 & -1.8116 & -0.0204 \\
\hline 8 & 0.0028 & -0.0316 \\
\hline 9 & 1.8033 & -0.0427 \\
\hline 10 & 2.9961 & -0.0501 \\
\hline 11 & -3.0088 & -2.1859 \\
\hline 12 & -1.805 & -2.1878 \\
\hline 13 & -0.0107 & -2.1907 \\
\hline 14 & 1.7701 & -2.1936 \\
\hline 15 & 2.9498 & -2.1955 \\
\hline
\end{tabular}

Gambar 8. Koordinat Foto Hasil Proyeksi

Dari gambar diatas dapat dilihat nilai parameter external kamera mulai stabil pada iterasi ke 3 memiliki perbedaan dengan nilai pendekatan awal, hal ini menandakan bahwa kamera digital Canon Ixus $115 \mathrm{HS}$ tidak stabil untuk keperluan fotogrametri sehingga perlu dilakukan proses kalibrasi terlebih dahulu.

\section{Analisis Parameter Internal Kamera}

Setelah mendapatkan nilai parameter external kamera selanjutnya menentukan Parameter internal kamera atau Interior Orientation Parameter (IOP) untuk mendapatkan unsur-unsur orientasi dalam antara lain panjang focus terkalibrasi $(f)$, posisi titik utama foto $\left(\mathrm{X}_{0}, \mathrm{Y}_{0}\right)$ dan koefisien distorsi lensa (K1,K2,K3,P1,P2) dengan memberi nilai pendekatan dan melakukan proses Bundle Adjustment Self Calibration sampai diperloeh parameter yang stabil.

\section{Perhitungan Parameter Internal Kamera}

Secara umum langkah yang dilakukan untuk menentukan nilai IOP adalah sebagai berikut :

1. Memasukkan 6 parameter external kamera yaitu $\omega, \phi, k$ dalam satuan radian, dan $X L, Y L$, $Z L$ dalam satuan millimeter kemudian dihitung dengan persamaan BASC.

2. Memasukkan koordinat foto dan koordinat Ground Control Point.

3. Kriteria akurasi focus $11 \mathrm{~mm}$, artinya iterasi akan berhenti jika nilai focus terkalibrasi 
mendekati atau sama dengan $11 \mathrm{~mm}$. Hasil lengkap perhitungan IOP dapat dilihat dibawah ini :

\begin{tabular}{|c|c|c|c|}
\hline Iterasi & 1 & 2 & 3 \\
\hline$\omega(\mathrm{rad})$ & -0.0495 & -0.0187 & -0.0271 \\
\hline$\varphi(\mathrm{rad})$ & 0.0442 & -44.6097 & $-3.57 \mathrm{E}+04$ \\
\hline $\mathrm{K}(\mathrm{rad})$ & 0.0091 & -2.3053 & $5.37 \mathrm{E}+03$ \\
\hline $\mathrm{Xl}(\mathrm{mm})$ & 48.8491 & $5.01 \mathrm{E}+05$ & $-2.97 \mathrm{E}+11$ \\
\hline $\mathrm{Y} 1(\mathrm{~mm})$ & 377.5675 & $3.79 \mathrm{E}+04$ & $3.14 \mathrm{E}+11$ \\
\hline $\mathrm{Zl}(\mathrm{mm})$ & $-9.31 \mathrm{E}+03$ & $7.12 \mathrm{E}+06$ & $2.90 \mathrm{E}+11$ \\
\hline Xo & -2.288 & 277.2345 & $-2.78 \mathrm{E}+05$ \\
\hline Yo & 8.862 & 373.4202 & $-1.33 \mathrm{E}+05$ \\
\hline $\mathrm{f}$ & -99.4367 & $-8.47 \mathrm{E}+03$ & $5.27 \mathrm{E}+05$ \\
\hline K1 & -0.2007 & -0.4018 & -0.5991 \\
\hline K2 & 0.0099 & 0.0199 & 4.5784 \\
\hline K3 & $-1.95 \mathrm{E}-06$ & $-1.12 \mathrm{E}-05$ & -0.265 \\
\hline P1 & $9.80 \mathrm{E}-04$ & 0.0017 & 0.0067 \\
\hline P2 & 0.0153 & 0.0321 & 34.0136 \\
\hline
\end{tabular}

Gambar 9. Nilai Parameter Internal Kamera (IOP)

Dari hasil kalibrasi kamera yang tertuang pada gambar diatas dapat diketahui bahwa nilai titik utama foto $\left(\mathrm{Xo}_{\mathrm{O}} \mathrm{Yo}\right)$ dan focus terkalibrasi $(f)$ yang dihasilkan tidak menghasilkan nilai yang stabil dan menghasilkan perubahan yang besar, sedangkan nilai parameter eskternal terkalibrasi dan jarak fokus mengalami perubahan yang signifikan, hal ini dapat disebabkan karena elevasi yang tidak bervariasi karena menggunakan satu foto yang diambil tegak lurus dengan kamera, seperti yang dikatakan (Wolf 1983) bahwa jika objek point memiliki elevasi (Z) yang sama mungkin tidak menghasilkan hasil yang memuaskan.

Pada penelitian yang dilakukan Hanifah (2007) dengan kamera Coolpix 2200, nilai focus terkalibrasi mengalami perubahan sebesar $1.753 \mathrm{~mm}$ ini dipengaruhi oleh jumlah foto yang diambil dan dari berbagai sisi. Untuk mengatasi problem ini mungkin diperlukan variasi elevasi objek untuk penelitian selanjutnya. Jadi dapat dikatakan bahwa kalibrasi kamera tidak menghasilkan nilai parameter yang stabil namun tetap dapat digambarkan model proyeksi antara koordinat GCP dengan koordinat hasil proyeksi.

\section{Analisis Distorsi}

Pada penentuan parameter orientasi luar didapatkan nilai kesalahan proyeksi koordinat foto, nilai ini adalah selisih dari koordinat GCP awal dengan koordinat baru yang didapatkan. Nilai reprojection error dapat dilihat dalam tabel berikut ini :

\begin{tabular}{|c|c|c|}
\hline Titik & $\mathrm{x}(\mathrm{mm})$ & $\mathrm{y}(\mathrm{mm})$ \\
\hline 1 & 0.0032 & 0.0224 \\
\hline 2 & 0.0139 & 0.0015 \\
\hline 3 & -0.0042 & -0.0078 \\
\hline 4 & -0.0057 & 0.0014 \\
\hline 5 & 0.0163 & 0.0216 \\
\hline 6 & 0.016 & 0.0182 \\
\hline 7 & 0.019 & -0.0672 \\
\hline 8 & -0.0026 & 0.0071 \\
\hline 9 & -0.0273 & 0.0051 \\
\hline 10 & -0.0102 & 0.0038 \\
\hline 11 & -0.0195 & -0.0156 \\
\hline 12 & 0.004 & 0.0022 \\
\hline 13 & -0.0022 & 0.0175 \\
\hline 14 & -0.0096 & 0.0025 \\
\hline 15 & 0.0083 & -0.013 \\
\hline
\end{tabular}

\section{Gambar 10. Reprojection Error Koordinat Foto}

Arah distorsi antara koordinat foto dengan koordinat hasil proyeksi dapat digambarkan seperti gambar dibawah ini :

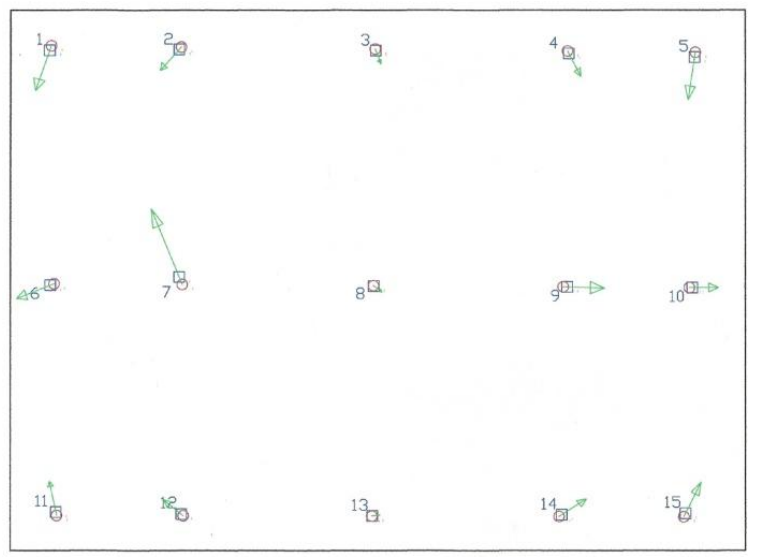

Gambar 4. Model Distorsi Hasil Proyeksi Keterangan :

$\begin{array}{ll}\square & =\text { Titik GCP } \\ \bigcirc & =\text { Titik Reproyeksi } \\ \longrightarrow & =\text { Arah Distorsi } \\ \text { Skala vector } & =1: 10\end{array}$


Dari gambar diatas dapat dilihat bahwa arah pergeseran titik setelah diproyeksi mengalami pergeseran yang tidak besar, besar nilai reprojection error pada tabel 4.7 menunjukan kurang dari $0.5 \mathrm{~mm}$ dari bacaan maksimal mistar $1 \mathrm{~mm}$ sebagai acuan, hal ini dikarenakan penggunaan panjang focus normal $11 \mathrm{~mm}$ (equiv. $61,6 \mathrm{~mm}$ dalam sensor full frame). Untuk titik-titik yang berada di atas arah pergeseran cenderung ke atas, sedangkan titik-titik yang berada di tengah, pergeserannya cenderung mengarah ke titik pusat foto (o.o), lalu untuk titik-titik yang berada di bawah, pergeserannya cenderung ke arah luar hal ini menunjukkan bahwa kamera yang digunakan mengalami barrel distortion. Titik yang mengalami pergeseran terbesar yaitu titik 7 dengan nilai kesalahan $0.019 \mathrm{~mm}$ ke arah $X$ dan $0.0672 \mathrm{~mm}$ ke arah $Y$ dan titik yang mengalami pergeseran terkecil yaitu titik 8 yang berada di pusat foto dengan nilai kesalahan

$0.0026 \mathrm{~mm}$ ke arah $X$ dan $0.0071 \mathrm{~mm}$ ke arah $\mathrm{Y}$ ini memperlihatkan bahwa titik-titik yang berada di tengah foto mengalami pergeseran yang tidak besar.

\section{KESIMPULAN DAN SARAN}

\section{Kesimpulan}

Dari hasil penelitian dapat disimpulkan bahwa:

1. Kamera Canon Ixus 115 HS memiliki parameter Eksternal yang stabil dan distorsi hasil proyeksi dengan arah pergeseran yang mendekati posisi ideal dan nilai reprojection error tidak melebihi $0.5 \mathrm{~mm}$ dari bacaan maksimal mistar $1 \mathrm{~mm}$, hal ini dapat disebabkan karena penggunan panjang fokus normal, yaitu $11 \mathrm{~mm}$ atau setara $61,6 \mathrm{~mm}$ pada sensor full frame. Proses kalibrasi yang dilakukan pada kamera Canon IXUS 115HS tidak menghasilkan parameter internal yang stabil, panjang focus mengalami perubahan signifikan sebesar $-99 \mathrm{~mm}$ dari nilai acuan $11 \mathrm{~mm}$, dan nilai parameter external terkalibrasi berbeda jauh dari nilai awal yang diberikan. Hal ini dapat disebabkan karena elevasi (Z) yang tidak bervarisasi.

2. Model distorsi dapat digambarkan berdasar koordinat reproyeksi foto terhadap koordinat awal foto. Titik yang mengalami pergeseran terbesar yaitu titik 7 dengan nilai kesalahan
$0.019 \mathrm{~mm}$ ke arah $\mathrm{X}$ dan $-0.0672 \mathrm{~mm}$ ke arah $\mathrm{Y}$ dan titik yang mengalami pergeseran terkecil yaitu titik 8 yang berada di pusat foto dengan nilai kesalahan $-0.0026 \mathrm{~mm}$ ke arah $\mathrm{X}$ dan $0.0071 \mathrm{~mm}$ ke arah $\mathrm{Y}$ ini memperlihatkan bahwa titik-titik yang berada di tengah foto mengalami pergeseran yang tidak besar. Arah distorsi untuk titik yang berada diatas dan dibawah cenderung bergeser menjauh dari sumbu utama, sedangkan titik yang berada di tengah foto mengarah ke sumbu utama.

\section{Saran}

1. Untuk penelitian selanjutnya dapat diteliti kemungkinan penggunaan variasi foto bidang kalibrasi sehingga menghasilkan variasi elevasi objek kalibrasi untuk menghasilan parameter internal yang stabil dan akurat.

2. Sebaiknya pengambilan foto objek hendaknya memperhatikan kondisi lingkungan di sekitar objek, agar dicapai kondisi semirip mungkin dengan kondisi lingkungan pada saat kalibrasi kamera dilakukan.

\section{DAFTAR PUSTAKA}

KALIBRASI KAMERA NON-METRIK DIGITAL DENGAN METODE SELF CALIBRATION

Bayu Angkusprana Saktia Putera dan Dr. Ing. Ir. Teguh Hariyanto,M. Sc.

Jurusan Teknik Geomatika ITS-Sukolilo, Surabaya 60111

Email: Afriyanti, R. 2005. Pembuatan Peta Foto Dengan Metode Mosaik Semi Terkontrol Menggunakan Foto Udara Format Kecil Non Metrik. Tugas Akhir. Institut Teknologi Sepuluh Nopember. Surabaya

Atkinson. K.B. 1996. Close Range Photogrammetry and Machine Vision. Whittles Publishing. Scotland, UK.

Atkinson. 2000. Theory of Close Range Photogrammetry, Ch.2 Coordinate Transformations.http://www.lems.brown.edu/visi on/people/leymarie/Refs/Photogrammetry/Gener al.html

Cooper, M.A.R., dan S. Robson. "Theory of Close Range Photogrammetry." Dalam Close RangePhotogrammetry and Machine Vision, oleh K.B. Atkinson. Scotland: Whittles Publishing, 1996.

Dipokusumo,B.S., 2001. Pengantar Fotogrametri. Bandung : Departemen Teknik Geodesi ITB.

Fryer, J.G. "Camera Calibration for Non Topographic Photogrammetry." Dalam Non Topographic Photogrammetry, oleh H.M. Karara. ASPRS, 1989. 
Hanifa, N.R. 2007. Studi Penggunaan Kamera Digital Low Cost Non Metric Auto Focus Untukpemantauan Deformasi. Thesis. Institut Teknologi Bandung. Bandung

Harintaka,dkk. 2008. "Pemodelan ketidakstabilan kamera dan gerakan Pesawat pada saat pemotretan Foto udara format kecil". Yogyakarta : Universitas Gadjah Mada

Harintaka, 2003, Penggunaan Persamaan Kolinier Untuk Rektifikasi Citra Satelit SPOT Secara Parsial, Media Teknik, Edisi Mei, Fakultas Teknik, Universitas Gadjah Mada.

Hidayat, H. 2012. Optimalisasi image-based architectural Modeling pada googld sketchup Menggunakan kamera amatir digital Terkalibrasi. Tugas Akhir, Institut Teknologi Sepuluh Nopember, Surabaya.
Kusudarma, A. 2008. Aplikasi Close Range Photogrammetry Dalam Pemetaan Bangun Rekayasa Dengan Kamera Dijital Non Metrik Terkalibrasi. Tugas Akhir, Institut Teknologi Bandung. Bandung.

Lillesand, T.M. dan Kiefer,R.W., 1990. Penginderaan Jauh dan Interpretasi Citra. Yogyakarta : Gadjah Mada University Press.

Rockwell, K. 2010. Canon IXUS 115HS and G11 Reviews, <URL: http://www.kenrockwell.com/canon.htm>.

Wijayanti, M. 2008. Ujicoba Penentuan Unsur-Unsur Orientasi Dalam Kamera Digital Non-Metrik Dengan Metode Pendekatan Sederhana Studi Kasus : Kamera Nikon Coolpix 7900. Tugas Akhir. Institut Teknologi Bandung. Bandung.

Wolf, P.R., 1983, Elements of Photogrammetry, 2nd edition, McGraw-Hill Book Company, USA. 